\title{
Correction to: Philosophy of sustainability experimentation experimental legacy, normativity and transfer of evidence
}

\section{Milutin Stojanovic ${ }^{1}$ (1)}

Published online: 13 December 2021

(c) Springer Nature B.V. 2021

\section{Correction to: European Journal for Philosophy of Science https://doi.org/10.1007/s13194-021-00383-4}

In the original version of this article, the given and family names of the author were switched as Stojanovic Milutin. The correct name is Milutin Stojanovic.

The original article has been corrected.

Publisher's Note Springer Nature remains neutral with regard to jurisdictional claims in published maps and institutional affiliations.

The original article can be found online at https://doi.org/10.1007/s13194-021-00383-4.

Milutin Stojanovic

milutin.stojanovic@helsinki.fi

1 Helsinki Institute of Sustainability Science (HELSUS) and Practical Philosophy, University of Helsinki, Helsinki, Finland 